\title{
Marginalization in Globalization
}

\author{
Chinese Polemics on the Specifics \\ of Russian Diplomacy
}

Alexander V. Lomanov

\section{Abstract}

The article analyzes approaches of modern Chinese scholars to the influence of history and culture on Russian diplomacy. It discusses key approaches and typical arguments in Chinese scientific publications. Chinese authors pay special attention to historical continuity and stability in Russian diplomacy and seek to integrate the analysis of its cultural foundations with geopolitical approaches and identify invariable components in Russia's foreign policy. Many Chinese scholars emphasize the realism of Russian diplomacy and its susceptibility to the "European complex" caused by Russia's unfailing attraction to the European

Alexander V. Lomanov, PhD in History, is a Professor and Head Research Fellow at the Institute of Far Eastern Studies, Russian Academy of Sciences (Moscow).

E-mail:a_lomanov@hotmail.com

SPIN Russian science citation index: 2960-1628

ResearcherID: B-5068-2018

SCOPUS AuthorID: 56153472700

Institute of Far Eastern Studies, Russian Academy of Sciences (IDV RAN),

32, Nahimovskii Prosp., Moscow 117997, Russian Federation

Tel.: +7 4991240213

E-mail: ifes@ifes-ras.ru

The article is based on a report made at the 18th International Scientific Conference on Economic and Social Development, held on April 11-14, 2017 at the Higher School of Economics in Moscow. The author thanks Fyodor Lukyanov (HSE) and Mikhail Troitsky (Moscow State Institute of International Relations) for their comments during the discussion of the report. 
civilization and the impossibility for it to become its full-fledged member. The article discusses assessments made by Chinese authors with regard to religious "Orthodox messianism," Russian nationalism, the sense of having a "historical mission," the "imperial syndrome," "marginality," and "great power hegemony" in Russia's present foreign policy as components of Russian political culture. The study of Chinese publications concludes that such interpretations are not part of the Chinese academic mainstream. Yet, they continue to be present in the Chinese scientific space and have an implicit influence on forecasts concerning Russia's foreign policy and on China's approaches to the development of interaction between the two countries. An important task is to find out how modern and independent the Chinese analysis of Russia's foreign policy is, and to what extent it copies stereotypes of Western political science with regard to Russia or polemical statements against the Soviet leadership, made in the 1960 s and the 1970s. Chinese assessments and general conclusions concerning the specifics of Russian diplomacy are of great interest, because they are made against the background of China's growing national awareness as a new rising power seeking to acquire its own style in foreign policy.

Keywords: China, scientific publications, Russia's foreign policy, culture, history, religion.

\section{STEREOTYPED VISION OF RUSSIA'S FOREIGN POLICY}

In the 1990s, articles about peculiarities of Russian diplomacy and its historical traditions began to regularly appear in Chinese scientific periodicals. A special academic genre has emerged since then, which combines discussions of specific aspects of Russia's foreign policy with broad generalizations about the Russian national character and the geopolitical and civilizational uniqueness of Russia.

Since the first post-Soviet decade, Chinese authors have tried to comprehend and generalize the experience of Russia's search for a new place in world politics. In the late 1990s, doctoral student Cao Zhiping of East China Normal University pointed out that after the break-up of the Soviet Union three geopolitical emphases had emerged in Russian diplomacy: "Atlanticism," priority for "neighborhood diplomacy," and "neo-Eurasianism." The latter, in the scholar's opinion, reflected Russia's internal needs and was a reaction to "the 
West's complete turnabout" within the framework of "Atlanticism" (Cao Zhiping, 1998).

The publication periodizes the development of Russia's foreign policy, which quickly restored the balance of priorities. Whereas immediately after the Soviet Union's break-up Moscow tilted towards the West, already in May 1992 it proclaimed "equal attention to the East and the West" or "two-headed eagle diplomacy." In April 1994, Russia adopted a "diplomatic strategy of a big state," and in 1995 a "comprehensive diplomatic strategy." In 1996, after Yevgeny Primakov was appointed foreign minister, Moscow made a step towards "all-round diplomacy."

The Chinese scholar explained these dynamics by Russia's cultural tradition. The country's status as a third-type civilization (neither Western nor Eastern, but Eurasian or "synthetic") formed a "geopolitical awareness" that, combined with history, culture and national psychology, constitutes the "Russian idea." Due to its special geopolitical position on the Eurasian continent, Russia developed a sense of being a "great state" and a sense of superiority. Its proximity to Europe and Asia led to the dualism of national self-assessment and its projection to the outside world. "In the face of backward Asia, Russia demonstrated in every way that it had advantages over advanced and strong Europe;" however, the same factors made it feel humiliated before developed Europe which looked down on Russia (Cao Zhiping, 1998: 56).

Chinese authors pay special attention to the duration and stability of Russian diplomacy, its ability to maneuver and make tactical changes, and the diversity of approaches it uses to resolve conflicts. As geopolitical factors have the longest influence on the country's diplomatic tradition, "continental" Russia invariably seeks to acquire and protect approaches to seaports, prevent transport blockades, and avoid simultaneous conflicts with several powerful opponents. "Whether Russia used an expansive or defensive policy, the avoidance of enmity with two or more states was of paramount importance for Russian diplomacy, especially if it was opposed by strong enemies" (Du Zheng'ai, 2005: 45).

Many Chinese scholars try to find traces of the unique "culture of Eurasianism" in the foreign policy of post-Soviet Russia. Master's 
Degree student Xiao Guichun of the Sichuan International Studies University pointed out that Primakov's appointment as foreign minister "marked the completion of transition in Russia's foreign policy from Westernization to Eurasianism." The author noted that President Vladimir Putin had inherited a policy of multi-vector diplomacy which balances the East and the West. In order to achieve the goal of building a "rich state with a strong people" (guo fu min qiang-this formula makes this goal identical to the ideal of national prosperity and power, dating back to ancient Chinese culture), the Russian leader put forward the idea of Eurasian presence-a European vector and an Asian vector-in foreign policy (Xiao Guichun, 2008: 43).

Articles on Russian diplomacy written by graduate students of Chinese provincial universities often depict a stereotyped vision of Russia. The author of one of them believes that the Russian diplomatic strategy in the 21 st century is influenced by a political culture characterized by a "sense of having a historical mission," the feeling of being "on the fringes of the world," and an "imperial syndrome" (Zhang Min, 2002).

In this interpretation, the "sense of having a historical mission" is tied to the religious factor and Byzantine aspiration to become "the center of the Christian world." The idea of "Holy Russia" implies possessing the true faith which other peoples do not have: after Russia's liberation from the Mongol yoke, this idea evolved into the Third Rome theory, which later became widespread. The historical mission of uniting the entire Christian world became the ideological basis of Russian expansion. In Russia's foreign policy, the "sense of having a historical mission" gave rise to great-power hegemony, which does not allow the country to demonstrate its weakness and form an alliance with a stronger partner.

"Marginality" stems from the country's location between the West and the East. It allows Russia to conduct multi-vector diplomacy. But since Russia's prosperity and decline have to do with the West, it makes the main emphasis in its diplomacy on relations with the West (let us not forget that the article was published a decade and a half ago).

The author explains the "imperial syndrome" in Russia's foreign policy by quoting Zbigniew Brzezinski and the "security paradox" 
when a sense of external danger causes the country to resort to expansion, which only increases the sense of danger and leads to further expansion, thus trapping the country within a vicious circle. The brief article concludes that the Soviet Union's break-up seriously complicated the life of people in Russia, which turned "from paradise to hell," and gave rise to authoritarianism and the revival of nationalism. In the 21st century, Russian diplomacy "undoubtedly" bears the traces of the "imperial syndrome" of Russians (Zhang Min, 2002: 43).

Professor Zhang Jianhua of the School of History of Beijing Normal University points out that Russian diplomacy is influenced by a historical tradition based on geopolitical and cultural specifics (Zhang Jianhua, 2005).

Firstly, this tradition determined the goals of Russian foreign policy. Choosing between the West and the East has always been difficult for Russia. Modern Russia has largely inherited the territorial possessions of tsarist Russia and the Soviet Union and the geopolitical cultural tradition, which implies that the difficulty of diplomatic choice has remained unchanged.

Secondly, the universalism of culture has determined a long-term trend for Russia's foreign policy. According to the Chinese historian, this universalism is "extremely noticeable" and is closely linked with Orthodox dogmas, namely, "salvation of the Slavic world," a great mission of the Russian people, and emphasis on the specifics of Russia's path and its mission as "the liberator" of all peoples. Projecting these ideas to Russian foreign policy transforms them into patriotism extending to the point of chauvinism. After the collapse of tsarist Russia, the Soviet Union promoted its universal ideology around the world, its final manifestation being Mikhail Gorbachev's "new thinking" addressed to the whole of mankind.

Thirdly, the legacy of autocracy and authoritarianism, when all issues are in the sole competence of the "tsar", has created a discernible bias towards "chief executive diplomacy" in Russian foreign policy (Zhang Jianhua, 2005: 213-218).

Professor Li Guiying of the School of Humanitarian and Social Sciences of Changchun University writes that the main trait of Rus- 
sia's "diplomatic culture" is a conflict-ridden desire for Westernization combined with the "Eastern complex." The scholar thinks that, after the liberation from the Mongol yoke, Russians felt a threat from the West and psychologically rejected Western values. After 1992, the Russian experience of building a Western-style market economy proved unsuccessful. Western great powers pursued a policy of containment towards Russia, which again created enmity towards the West among Russian nationalists.

The second trait is "the advancement of the balance of power diplomacy among multipolar forces." Russia did not create the "balance of power" concept and very rarely mentions it publicly in diplomacy. History shows, however, that, even though it did not have any advantages over other countries, Russia quickly turned into a strong European state. One of the factors behind its success was its skillful use of the balance of power diplomacy which implied playing on differences between countries and their mutual containment in order to divide them. Li Guiying recalls that after its defeat in the Crimean War (1856), Russia successfully played on differences between Western powers. In the Soviet period, Russia used this diplomacy to conclude a treaty with Germany in Rapallo (1922), which helped it break out of international isolation. A similar policy was used on the eve of World War II: "From August 1939 to June 1941, torn among socialism, capitalism and Nazism, Stalin made a choice in favor of Nazi Germany to use the struggle among other states in order to provide the greatest security and benefits for his country" (Li Guiying, 2003: 29).

After the end of the Cold War, Russians came to the conclusion that the situation in Russia and its foreign-policy goals were in many ways similar to those in the era of Alexander Gorchakov. The country had actually lost the status of great power, so the traditional balance of power diplomacy became valid again. Russia began to build new ties, play on differences among countries, and use a strategy designed to maintain a multipolar balance of power. The East plays a special role for Russia in maintaining the balance with the West. It also needs to develop the economy of Siberia and the Russian Far East. This is why Putin's all-round diplomacy pays more and more attention to Asia. 
The third aspect is the ideologization of foreign policy, which has manifested itself in two ways: first, the desire to spread one's ideas and values around the world and make them normative, and second, the ruling elite saw the outside world through the mirror of its own ideology and on this basis made conclusions about who was a friend and who was an enemy. As an example of ideological motivation, the Chinese author mentions tsarist Russia's support of monarchical absolutism in European countries in the first half of the 19th century.

The scholar concludes that post-Soviet Russia did not abandon ideology in foreign policy but merely replaced "socialist theory" with a slogan of "freedom and democracy." For the sake of creating an ideological guarantee for the development of good relations with the West, the Russian leadership proclaimed that Russia and the West would pool their efforts in the name of democracy and market freedom ( $\mathrm{Li}$ Guiying, 2003, p.30). The excessive emphasis on the ideological dimension of Russia's foreign policy served as the basis for an unfulfilled belief that Russia, which declaratively shared Western values, would not be opposed to NATO's enlargement.

\section{BALANCE OF POWER DIPLOMACY}

The discussion of Russian diplomacy through the prism of Nikolai Berdyaev's philosophical ideas and Zbigniew Brzezinski’s geopolitical constructs has become very popular in China over the past decade. Doctoral student Zhao Shufang of the Institute for International Strategic Studies at the CPC Central Party School, discussing specifics of Russian diplomacy, highlights "Westernization and the Eastern complex," "the sense of insecurity, expansionism and the sense of being a great state," "ideology and the sense of having a historical mission," and "the balance of power diplomacy and the law of the sword." Russia was weak compared to the West, yet it could seize territories in the East. This thesis is borne out by Friedrich Engels' words that diplomacy was as important to Russia as the army. The author suggests that in Russia's Eastern policy diplomacy served as an "appendage to and a result of" military operations (Zhao Shufang, 2004: 52). 
In the scholar's opinion, all these characteristics are still present in Russia’s diplomacy. Russia develops relations with the West, although it feels a "mixture of love and hatred" towards it. Even though the difficulties of the post-Soviet years have led to the revival of the ideas of Russian Eurasianism and the strengthening of political authoritarianism, the era of globalization makes it impossible for Russia to return to the past. "Even if the idea of equal importance of the East and the West has gained popularity in Russia, the trend towards Westernization of values is fairly noticeable. Generally speaking, it is Westernization, only its pace and forms may differ. In foreign policy, the West will continue to be the most important direction" (Zhao Shufang, 2004: 52).

Secondly, due to the significant changes in geopolitics and real power, imperial views increasingly often evolve into a "desire for revival." The author recalls that after the Soviet Union broke up, Russia's territory and economy shrank and, according to Brzezinski, it became a weak and India-like country, with the exception of several cities.

"However, over centuries, Russia has become accustomed to being treated as a world power; the imperial syndrome cannot disappear overnight, and the desire to acquire the status and play the role of a strong world state is Russia's invariable strategic goal. Economic revival, military build-up, greater perseverance in dealing with difficulties, and 'memories of Russia's status of a great state during the last three hundred years' are the most important tools for achieving this goal. When Putin came to power, he clearly stated that he would make efforts to revive the Russian economy, restore Russia's image of a great state and strengthen the unity of the nation. All these factors will certainly have a strong impact on Russia's foreign policy" (Zhao Shufang, 2004: 53).

Thirdly, the old ideology collapsed, and Russia has lost the ability to promote the idea of "saving the world." According to the Chinese scholar, historically the Russian people has always needed a unifying and collectivist ideology, including the idea of a great mission. Without such an ideology, Russia inevitably plunges into chaos and decay. Orthodoxy in tsarist times and communism in Soviet times were such ideologies, and the need for an ideology like that will persist in Russia in the future, too. 
Fourthly, the concept of a "two-headed eagle" causes Russia to pay attention both to the East and the West. "On the first level, it plays the Western card in relations with the East, and the Eastern card in relations with the West, making every effort to maximize its own benefits. On the second level, it seeks to maintain the balance of power between Western and Eastern countries, prompting them into mutual containment so that they pose no threat to Russia" (Zhao Shufang, 2004: 54).

Many Chinese researchers explain the difficulties faced by Russia in looking for an identity in the contemporary world by a restraining influence of tradition, history and national mentality. The emphasis on continuity and invariability often prevented the Kremlin from seeing and accepting new developments and changes that had taken place after the Soviet Union's break-up and the end of the Cold War. As an example of a balanced approach, I can mention an article by Chen Xiaoqin (School of International Studies, Renmin University of China), who singles out three key features of Russian diplomacy.

The first one is all-round balance diplomacy. Since the end of the Cold War, Russia’s foreign policy has moved from a "tilt" towards the West to the "two-headed eagle" policy to multi-vector diplomacy. History has shown that the loss of balance between the East and the West in Russia's foreign policy "does not correspond to geopolitical reality."

The second feature is pragmatic diplomacy of protecting state interests, based on the concept of a multipolar world, in which Russia wants to become one of the centers of influence. "At the present stage, Russian diplomacy demonstrates practicality, vigor, activity, clarity of purpose, and energy, and does the best it can to protect its own interests" (Chen Xiaoqin, 2007: 36).

The third one is active diplomacy upholding the status of great power. A common feature running through Russian diplomacy under both Yeltsin and Putin is the desire to restore the country's former glory on the international scene: "The concept of a multipolar world can be viewed as a Russian tactic to revive the great state, since it is only a multipolar world that meets its national interests as a geopolitical power."

The article was published shortly before the end of Putin's second presidential term. The author made a noteworthy forecast that "no 
matter who comes to power after 2008, Russia, as a great world power, will advance along the path of revival, combining its national specifics with geopolitical reality, and will diligently fulfil the historical dream of a strong state with a rich people (in Chinese political rhetoric, this tenet is interchangeable with the aforementioned phrase 'a rich state with a strong people'-author)" (Chen Xiaoqin, 2007: 37).

\section{MESSIANISM AND REALISM IN RUSSIA'S FOREIGN POLICY}

At the beginning of this decade, Zhang Hong and Liu Huibao of the School of Advanced International and Area Studies at East China Normal University analyzed "the conceptual structure and transition period" of Russian diplomacy. Among components of this structure, they singled out "a synthetic form of civilization," "the state idea" and "the ideology of a strong power" elevated to the level of principles, "the spirit of communality," "the ideology of power concentration," "religious ideology," "the idea of messianism," "the sense of insecurity" and "the imperial complex" (Zhang Hong and Liu Huibao, 2011).

The authors concluded that the specific features of the Russian civilization were the reason behind the "contradictions and difficulties" in identifying the place of Russian diplomacy. "Slavism" linked with Orthodox culture and embellishing everything Russian, "Atlanticism" which admires the West and its values, and "Eurasianism" which is in-between them, cannot achieve unity, thus pushing the situation off balance. Orthodox religiosity and the "messianic mission" serve as a "guide to action" for Russian diplomacy—the religious ideas of patience and asceticism help the country endure difficult times and wait for a new revival of the "empire," based on the idea of Russia's spiritual uniqueness as a post-Byzantine "third Rome." A combination of "messianism" and the "imperial complex" led to Russia's decisive actions during the Georgia conflict in August 2008, which came as a complete surprise to the West. The ideas of statism, communality and power concentration have ensured "institutional continuity" for Russian diplomacy. "In diplomacy, Russia craves for the realization of its dream of empire; this is why, based on a clear understanding of the national idea, it is creating effective 
institutional codes and foreign-policy logic" (Zhang Hong and Liu Huibao, 2011: 91).

Chinese Master's Degree students still willingly share their general views on Russia's diplomatic tradition. An article published in 2014 described its main components as follows: a "geopolitical view of security," a "symbiosis of the Eastern and Western civilizations," "balance of power diplomacy," and "religious salvationism and the idea of a great state." From this point of view, the development of Russia as a great state has always been characterized by "great order after great disorder," which is true for foreign policy, as well. "Traditional components in Russia's relations with the outside world should not be ignored in analyzing and forecasting Russian foreign policy" (Chen Luping, 2014: 80).

The article repeats the idea that Russia has historically found itself trapped in the "security paradox," when continuing territorial expansion leads to an even greater sense of danger. It describes "control over the sphere of influence" as the core of Russia's view of security. The author sees manifestations of this control everywhere in Russian history, ranging from territorial expansions under Ivan IV, Peter the Great and Catherine the Great, to "the signing of the Collective Security Treaty by post-Soviet countries," to "opposition to NATO's eastward enlargement" and "color revolutions," to "the Russian-Georgian conflict" (Chen Luping, 2014: 79).

The article names, as indispensable attributes of Russia's policy, attempts to sow discord among great powers and play on differences among them, and act using the tendency towards a variety of forces. The Soviet-German non-aggression pact of 1939 is described as an attempt to form a "big triangle" in Europe, consisting of the Soviet Union, Germany, Britain and France. After the Soviet Union broke up, Russia's international positions weakened. To maintain the status of great power, it uses the international situation; therefore, the traditional "balance of power" diplomacy is regaining strength and prominence

The concept of religious salvation, as the basis of the Great Russia ideology, indicates the desire to assume the role of protector and ruler of the "Slavic world." "The Great Russia ideology meets the expansion- 
ist demands of the Russian Empire; together with the salvation ideology, it has become part of national mentality" (Chen Luping, 2014: 80).

The impact the above ideas have on Russia's current policy is manifested in the country's efforts to ensure security on its periphery, pursue the diplomacy of balancing between the East and the West, with greater attention to the West, and promote the idea of a multipolar international system and diplomacy of balance at various levels. Russia has abandoned the idea of empire and does not seek to restore the Soviet Union. At the same time, it seeks to restore its status of great power. This is where history, ideology, and politics again intertwine into one whole: "The great state idea has already penetrated deeply into the soul of the Russian nation, and Russians have embarked on the path of restoring the great state" (Chen Luping, 201: 80).

An article by another MD student, which describes the "tradition of realism" in Russia's foreign policy, says that the country's unique position on the Eurasian continent led to a clash between Eastern and Western components and their subsequent synthesis into a special Russian civilization. The territorial expansion resulted in the emergence of a large multi-ethnic state, where the Russian "great state complex" later developed. "From the times of Peter the Great and Catherine the Great to the times of Stalin, and right up to the new era of Putin's rule, this great state complex has continuously exerted a profound influence on Russia's policy towards the outside world" (Deng Nanfeng, 2014: 50).

Under the influence of external factors, Russian diplomacy has become active and diverse. At the same time, the article names, as a separate important factor, the "messianic complex" which "has got into the blood of the Russian people and transformed from a state ideology into a national ideology" (Deng Nanfeng, 2014: 51). According to the Chinese author, the geopolitical features and the "messianic complex," seen in the history of Russia, can serve as a starting point for studying the realistic tradition in Russia's foreign policy.

It should be admitted that articles written by beginning researchers, as a rule, only generalize and repeat what has been said by authoritative scholars. As distinct from these authors, Professor Li Xin 
of the Russian Language School of Capital Normal University has proposed his own interpretation (2016) of mechanisms through which the cultural tradition influences Russia's foreign policy. Describing positive aspects, he mentions the openness of Russian culture, which causes Russia to orient its foreign policy towards both the East and the West and believe in the importance of its role in connecting different civilizations. These views have allowed Russia to pursue "all-round diplomacy" and achieve a "dialectical unity of Asia-Pacific and EuroAtlantic criteria."

Secondly, Russian nationalism helps defend Russia’s independence and self-esteem. On the one hand, Russia has redefined its relations with Western countries, paying more attention to the protection of its own interests and seeking equal cooperation with other countries. On the other hand, in developing its foreign policy, Russia puts emphasis on a balance between the East and the West.

Thirdly, the Orthodox culture has rallied the Russian people; it helps stabilize the political situation and elevates the spirit of patience, which has become the essence of the Russian national character. Thanks to this factor, Russian diplomacy is capable of waiting; it continuously accumulates inner strength and seeks to restore Russia's status of a strong world power.

The "marginality" of Russian culture has a negative effect on diplomacy. Russia's geography not only leads to its openness but also to an insufficient "sense of belonging" to one of the world's civilizations, while its foreign policy wavers between the West and the East. There are hidden negative elements in Russian nationalism, which can evolve into racism, emphasizing the superiority of the Russian nation and placing its interests above other nations (Li Xin, 2016).

Chinese researchers constantly seek to compare the pros and cons of the impact of Russian culture on foreign policy. In 2004, a discussion of negative aspects reached the following conclusion: "Irrational elements of Russian nationalism or elements that push Russia into isolationism, rejection of advanced world experience and excessive protection of elements of national culture needing change lead Russia towards higher marginalization in the process of globalization, to- 
wards expansionism intended to distract a discontented population from domestic problems, and towards higher tensions in the world" (Zhang Ji and Zhang Aili, 2004: 132).

A similar conclusion is drawn in a 2016 article which points out that nationalism has brought about numerous conflicts in Russia's relations with other post-Soviet countries. "In the context of globalization, this foreign policy of Russia leads to its further marginalization; its extensive expansionism causes widespread discontent and increases tensions in the world" ( $\mathrm{Li}$ Xin, 2016: 249). The difference from the previous conclusion is that Russia's "expansionism" is not a means to distract a discontented population but a source of discontent itself.

Broad generalizations in Chinese scientific literature are based on interpretations of Russian history, starting from Peter the Great to the present day. According to some Chinese authors, this approach makes it possible to identify invariable components of Russian foreign policy and create tools to forecast it. The assumption about "triple succession" of the diplomacy of tsarist Russia, the Soviet Union and modern Russia accentuates the impact of tradition on decisions made by the Russian authorities. Chinese authors view elements of tradition as the source of realism in Russia's present foreign policy.

Many Chinese articles analyze the historical roots of Russia’s "European complex" and explain it by a combination of the country's gravitation towards European culture and everyday life and awareness of its own specific feature. Chinese authors emphasize that after the Soviet Union's break-up Russia's foreign-policy strategy was initially unsuccessful because it "tilted" towards "Atlanticism." It became successful only after Russia had returned to traditional approaches, namely, to invariant aspects created over centuries- "two-headed eagle diplomacy," "all-round diplomacy," "multipolarity" and, finally, Putin's "realism."

Chinese analysts see the success of Russian diplomacy in its ability to use different tactics in different periods while abiding by the invariable strategy of defending national interests. The phrase "policy of 
concealing abilities," borrowed from the Chinese political lexicon, as applied to Russia means that Putin does not back down and has combined strategic commitment to the defense of national interests with tactical flexibility. Chinese views on Russian diplomacy reveal a desire to understand another country's experience and, if possible, draw useful lessons from it.

Chinese authors emphasize that in the era of globalization Russian diplomacy has turned to realism while retaining its traditional features. In the post-Cold War period, its specific features include efforts to reach balance in all directions, pragmatism in defending national interests, and active protection of the status of great state. According to Chinese authors, the situation of "struggle without destruction" in Russian-European relations is also due to historical tradition.

Chinese conclusions about the presence of "Orthodox messianism," Russian nationalism, "historical mission," "imperial syndrome," "marginality," and "great power hegemony" in Russia's present foreign policy are open to debate. Chinese authors believe that the growth of Western pressure only consolidates Russian ideas about the national spirit and national values, which has an effect on diplomacy as well. However, an excessive interest in culturological and value subjects leads Chinese scholars to look for traces of the "Russian idea" everywhere in modern politics.

Russian sinologist Yuri Galenovich in the 2000s took note of attempts by authoritative Chinese scholars to present imperial expansion and religious messianism as essential attributes of Russia's "traditional political culture" (2009). The scholar warned that such conclusions could lead to discord between the two nations and create an obstacle to mutual spiritual understanding. Moreover, paradoxically such rhetoric is used by those who "sit in a glass house," because "the history of mankind is such that, if required, one can find the same 'weaknesses' or 'sore spots' everywhere" (Galenovich, 2009: 46).

The transition of modern China to an active foreign policy under the new slogan "Great Power Diplomacy with Chinese Characteristics" (zhongguo tese daguo waijiao), proclaimed by Xi Jinping in 2014, causes Chinese researchers to make remarkable reservations 
and terminological corrections. In order to avoid confusion with the Chinese foreign-policy concept, they have abandoned the term 'great state diplomacy' (daguo waijiao) when writing about Russia in favor of the term 'great power hegemony' (daguozhuyi) (Xing Yue and Wang Jin, 2017: 37, footnote 2). Their article drew the conclusion that the "messianic consciousness," which is the core of Russian culture, "has formed in Russians a 'great power mentality' of a 'God-chosen people', along with dependence and tolerance towards the government's authority. Their joint role makes Russian diplomacy manifest a very specific 'great-power' style" (Xing Yue and Wang Jin, 2017: 69).

The critical trend in Chinese publications discussing Russian political culture deserves attention and a closer examination. Chinese studies of Russian diplomacy reveal an increased interest in such factors as cultural identity and national character. Some authors repeat stereotypes about "inconsistency" of the Russian character and its "propensity for extremes," which supposedly results in Russia lacking restraint in foreign policy. Other stereotypes include "radical idealism" and, at the same time, "ultra-conservative realism" of Russian diplomacy, which constantly tries to balance between the "Eastern mind" and "Western appearance."

Chinese publications about the specific features of Russian diplomacy have an obvious sign of civilizational, religious and geopolitical determinism. It should be emphasized that this line of research is not part of the scientific mainstream; rather it can be compared to an undercurrent that is hardly noticeable for an occasional observer. As a rule, the authors of such articles are experts in history, culture, language or literature. There are also many beginning researchers among them. Experts in international affairs, who also take part in discussions, on the contrary, often do not have professional knowledge of Russia. A study of references cited in articles suggests that, apart from stereotypes already existing in Chinese scientific literature, authors use biased interpretations borrowed uncritically from Western publications in political science and cultural studies.

Yet publications of the Chinese "cultural and historical school" studying Russian diplomacy deserve attention, as they are a concen- 
tration of stereotypes used by the Chinese in judging current affairs and making forecasts for the future. These stereotypes were not born yesterday. Suffice it to recall the fierce criticism of Soviet foreign policy during the hectic years of the 1960s-1970s when it was equated in China to the "aggressive" policy of pre-revolutionary Russia, and when Soviet leaders were described as "new tsars." This intellectual genealogy can be extended further into the first half of the 20th century and include, for example, the autumn 1925 discussion by the Beijing intelligentsia of whether Soviet Russia, as a "country of red imperialism," was an irreconcilable enemy of China.

Another interesting question is what place the inertia of exposing "Soviet hegemonism," inherited from the past, occupies in modern Chinese studies. It is important to understand, in detail and with reliance on primary sources, to what extent the Chinese analysis is independent and to what extent it uncritically copies stereotypes of Western political science. Probably, some of these stereotypes were borrowed even before the beginning of the Cold War, in the first half of the 20th century when the West had a profound impact on ideological trends in Republican China.

Even the most controversial Chinese assessments and generalizations concerning specific features of Russian diplomacy are of interest, as they are formulated not from the Western point of view but from the position of China as a new rising power seeking to create its own specific national style in diplomacy. These assessments need to be studied and taken into account when discussing prospects for the development of Russian-Chinese interaction.

\section{References}

Cao Zhiping, 1998. Diyuan zhengzhi yu Eluosi waijiao [Geopolitics and diplomacy of Russia]. Dong'ou Zhongya yanjii, 5, pp. 54-61.

Chen Luping, 2014. Eluosi waijiao chuantong ji qi yingxiang [Russian diplomatic tradition and its influence]. Lilun guancha, 94(4), pp. 79-80. 
Chen Xiaoqin, 2007. Eluosi waijiao chuantong yu lengzhan hou E waijiao zhengce de tedian [Russian diplomatic tradition and specifics of Russian foreign policy after the Cold War]. Xiboliya yanjiu, 34(6), pp. 33-37.

Deng Nanfeng, 2014. Eluosi waijiao de xianshizhui chuantong [The tradition of realism in Russian diplomacy]. Guangxi jiaoyu xueyuan xuebao, 130(2), pp. 49-51.

Du Zhengai, 2005. Diyuan tedian dui Eluosi waijiao chuantong de yingxiang [The influence of geopolitics on Russian diplomatic tradition]. Waijiao xueyuan xuebao, 80(1), pp. 42-49.

Du Zheng'ai, 2007. Eluosi waijiao chuantong yanjiu [The study of Russian diplomatic tradition]. Shanghai: Renmin chubanshe. 369 pp.

Galenovich Yu. M., 2009. Kitai: kak traktuetsia "traditsionnaia politicheskaia kultura Rossii” [China: How it interprets Russian traditional political culture]. Aziia i Afrika segodnia, 11, pp. 42-46.

Liang Qichao, 1925. Fu Mianji shu lun dui E wenti [My answer to Mianji with regard to the discussion of the Russia problem]. Chenbao shehui fukan (4), p. 13

Li Guiying, 2003. Eluosi duiwai zhengce de waijiao wenhua bei jing [Diplomatic cultural background of Russia's foreign policy]. Changchun daxue xuebao, 13(4), pp. 28-30.

Li Xin, 2016. Eluosi waijiao wenhua yinsu dongyin fenxi [Motivational analysis of the cultural components of Russian diplomacy]. Renmin luntan, 11, pp. 247249.

Tikhvinskii, S. L., 2008. Vospriiatie v Rossii obraza Kitaia [Russia's perception of China]. Moscow: Nauka. 246 pp.

Xiao Guichun, 2008. Eluosi waijiao zhong de ouyazhuyi wenhua tezheng [Eurasian cultural specifics of Russian diplomacy]. Xiboliya yanjiu, 35(5), pp. 41-44.

Xing Yue and Wang Jin, 2017. "Misaiya yishi” yu Eluosi "daguozhuyi” waijiao ["Messianic mentality" and "great-power" diplomacy of Russia]. Guoji zhengzhi kexue, 1, pp. 36-70.

Zhang Hong and Liu Huibao, 2011. Guannian jiegou yu zhuanxing shiqi de Eluosi waijiao [The conceptual structure and transition period of Russian diplomacy]. Dongnanya zongheng, 9, pp. 86-91. 
Zhang Ji and Zhang Aili, 2004. Shi xi wenhua yinsu dui Eluosi waijiao zhengce de yingxiang [An attempt to analyze the influence of cultural components on Russia’s foreign policy]. Dangdai shijie yu shehuizhuyi, 3, pp. 127-132.

Zhang Jian, 2018. Pujing di si jie zongtong renqi de Eluosi waijiao quxiang [The tendencies of Russian diplomacy during Putin's fourth presidential term]. Heping yu fazhan (2), pp. 58-71

Zhang Jianhua, 2005. Eluosi waijiao quxiang de lishi wenhua chuantong sikao [Reflections about historical cultural traditions of Russian diplomacy]. Shijie jinxiandai shi yanjiu. 2. Beijing: Zhongguo shehui kexue chubanshe, pp.201219

Zhang Min, 2002. Cong zhengzhi wenhua toushi xin shiji Eluosi waijiao zhanlüe [Looking at Russia’s diplomatic strategy from the angle of its political culture]. Shanxi shifan daxue xuebao (zhexue shehui kexue ban), Vol.31. Supplement (Zhuan ji), pp. 41-43.

Zhao Shufang, 2004. Eluosi waijiao wenhua de tedian ji yingxiang [The specifics and influence of Russian diplomatic culture]. Dongbeiya luntan, 13(4), pp. 50-54. 